\title{
CHARACTERIZATION OF THERMALLY MODIFIED SHORT AND LONG ROTATION TEAKS AND THE EFFECTS ON COATINGS PERFORMANCE
}

\author{
Lisa Adina Pratiwi' ${ }^{1}$,Wayan Darmawan ${ }^{1, \star}$, Trisna Priadi ${ }^{1}$, Béatrice George ${ }^{2}$, André Merlin'2, \\ Christine Gérardin'2, Stéphane Dumarçay², Philippe Gérardin ${ }^{2}$
}

\begin{abstract}
Many wood processing industries use short rotation teak, which has lower quality especially in durability and dimensional stability. Heat treatment is an eco-friendly method to improve dimensional stability and durability of wood. The objectives of the study were to investigate the effects of thermal modification on chemical composition, colour, dimensional stability and durability as well as coating's performance after accelerated weathering of short and long rotation teak for exterior utilization. In this study, the samples were heated in oven at $220^{\circ} \mathrm{C}$ for $20 \mathrm{~h}$ under nitrogen atmosphere. Results showed that independently of growth conditions teak woods underwent hemicelluloses degradation and an increase of lignin content after heat treatment. Extractives contents were lower in short rotation than in long rotation teak, and decreased in all cases after heat treatments. Dimensional stability was considerably improved as indicated by anti-swelling efficiency values of $64,9 \%$ and $58,9 \%$ for short and long rotation teak, respectively. Heated teak woods were more resistant against Trametes versicolor and the durability of short-rotation teak increased from moderate to very durable. Coatings on heat treated teaks had better bonding quality and better photo-stability when compared to unheated. Heated short rotation teak could be considered for exterior application.
\end{abstract}

Keywords: Dimensional stability, durability, heat treatment, Tectona grandis, weathering.

\section{INTRODUCTION}

Teak is one of the most popular tropical hardwood species and the principal commercial timber in Indonesia, especially in island of java. Most teak tress are planted in plantation forest by Perhutani (a state forest enterprise) with long rotation ages (40 to 60 years). Perhutani teak has outstanding quality such as high dimensional stability, resistant to decay and termites, aesthetics wood color, and good workability properties (Bhat and Florence 2003, Martawijaya et al. 2005, Darmawan et al. 2006, Miranda et al. 2011, Lukmandaru 2011). Recently, wood industries have faced a supply shortages of long rotation teak, which has necessitated the harvesting of younger trees in a rotation period of less than 15 years from plantation and farmland stand. Logs from short rotation teak contain a large proportion of sapwood and juvenile wood, whose have different properties from long rotation teak (Richter et al. 2003, Darmawan et al. 2015). Heartwood formation begin to form between 4 and 6 years old in short rotation plantation teak trees (Moya et al. 2014). According to Darmawan et al. (2015), in 10 years old, heartwood portion is $40 \%$, meanwhile juvenile portion is $100 \%$, and mean diameter

\footnotetext{
${ }^{1}$ Department of Forest Products, Faculty of Forestry, Bogor Agricultural University, Indonesia.

${ }^{2}$ Laboratoire d'Etudes et de Recherche sur le Matériau Bois (LERMAB), Université de Lorraine, Faculté des Sciences et Technologies,

Vandoeuvre-lès-Nancy Cedex, France.

"Corresponding author: wayandar@indo.net

Received: 26.02.2018 Accepted: 02.10.2018
} 
growth is about $2,5 \mathrm{~cm} /$ year. The main concern of short rotation teak are with regard to stability and durability. High $\mathrm{T} / \mathrm{R}$ ratio $(2,45-2,97)$ in short rotation teak indicates dimensional instability and easily to deformation when dried (Basri and Wahyudi 2013). And also, lower extractive content related to lower durability in juvenile teak wood (Haupt et al. 2003, Thulasidas and Bhat 2007 Lukmandaru and Takahashi 2008).

Thermal modification is one of wood modification that improve decay resistance, dimensional stability, weathering performance, reduce water absorption, and darken materials (Hill 2006). In Europe, research on thermally modified wood has been the object of important investigations during the last decades leading to the development and industrialization of numerous processes based on different technologies differing mainly by the nature of atmosphere used during treatment (steam, nitrogen, oil, vacuum) and by the nature of heat transfer (convection or conduction) (Gérardin 2016). Retification process, which was used during this study, was developed in France. This process is carried out at $210^{\circ} \mathrm{C}$ to $240{ }^{\circ} \mathrm{C}$ in an inert atmosphere with less than $2 \%$ in oxygen (Vernois 2001). The technology of heat treatment provides an environmental safe method without using toxic chemical (Vu and Li 2010).

Some studies have explained behaviour, processes, and characteristics of heated teak. Uribe and Ayala (2015) investigate the influence of heat treatment on dimensional stability of teak. The samples treated at increasing temperature 130 to $210{ }^{\circ} \mathrm{C}$ reduce their volumetric swelling after $24 \mathrm{~h}$ of water immersion $(1$ to $0,2 \%)$. In other study, heat treatment at $220^{\circ} \mathrm{C}$ has better results than 210 and $215^{\circ} \mathrm{C}$ regarding density, shrinking, and color changing in teak from Costa Rica (Méndez-Mejías and Moya 2016). Sapwood teak treated at 180 ${ }^{\circ} \mathrm{C}$ become more resistant to color changes after exposure UV radiation for $168 \mathrm{~h}$ (Garcia et al. 2014). Li et al. (2015) found strong relationship between increasing treatment temperature and main chemical component of steam heated teak. In accordance the previous publications, heat treatment should be valuable treatment applied on Indonesian teak in order to improve its properties.

The heat treatment of wood changes its chemical composition due to degradation of hemicelluloses and extractive compounds (Kamdem et al. 2002). As a consequence of chemical changes, high temperature treatment also overcomes some of the problems of instability developed resulting in a reduction in equilibrium moisture content (EMC) and the decreased rate of water uptake of dried wood (Hillis 1984). An increased durability of heat-treated beech wood against the white rot fungi depends on treatment temperature (Hakkou et al. 2006). However, heated wood exposed to weathering results in poor aesthetics because of the discoloration (Ahajji et al. 2009, Huang et al. 2012). Exterior utilization of heated wood need a coating for protecting from UV, humidity, and microorganism. The weather resistance of the heat-treated wood is improved by water or solvent-borne coatings. The heated wood and unheated wood without coating have the similar level of cracking despite the lower moisture content of heated wood (Jämsä et al. 2000). The coating performance of low permeability wood was better than that of high permeable wood (Roux et al. 1988).

The objectives of the work were to investigate the effect of heat treatment performed at $220{ }^{\circ} \mathrm{C}$ for $20 \mathrm{~h}$ under inert atmosphere on chemical composition, dimensional stability, decay resistance durability and accelerated weathering of short rotation teak for exterior utilization. Dimensional stability resulting from thermal modification would also be of interest relating to coatings performance (bonding quality and color resistance).

\section{MATERIAL AND METHODS}

\section{Samples tree origin}

Teak (Tectona grandis L.f) from farmland stand and Perhutani (a state owned enterprise) plantation forest, Java, Indonesia. Short rotation teak (SRT) and long rotation teak (LRT) were obtained. The plantation sites were located at Madiun ( $7^{\circ} 37^{\prime} 4901^{\prime \prime} \mathrm{S} / 111^{\circ} 31^{\prime} 28099$ ' E, $95 \mathrm{~m}$ above sea level) East Java for the LRT and Bogor (6 $6^{\circ} 35^{\prime} 23^{\prime}$ ' S / $106^{\circ} 47^{\prime} 29^{\prime \prime}$ E, 127 m above sea level) West Java for SRT. Differences in growing conditions (environment, genetics and silviculture) between East Java and West Java resulted variations in teak growth. Madiun East Java has an average rainfall below $2000 \mathrm{~mm} /$ year and dry conditions for 4-6 months with an average temperature of $29^{\circ} \mathrm{C}$. Bogor West Java has a high annual rainfall (average $3500 \mathrm{~mm} /$ year), and dry conditions for 2-3 months with an average temperature of $27^{\circ} \mathrm{C}$. Fast-growing clonal seeds have been selected and planted at nutrient-rich sites in farmland stand, whereas Perhutani has utilized seeds from its production areas.

The sample trees had straight stems, were free from external defects, and were selected to minimize tree- 
to-tree variation. Short rotation samples were sapwood (10 years old) otherwise long rotation samples were heartwood (40 years old). They had a height of branch-free stem ranging from 8 to $10 \mathrm{~m}$, and average diameter at breast height level of $30 \mathrm{~cm}$ for LRT and $25 \mathrm{~cm}$ for SRT.

\section{Heat treatment}

A number of 6 samples in size of $100 \mathrm{~mm} \times 10 \mathrm{~mm} \times 70 \mathrm{~mm}(\mathrm{~L}, \mathrm{~T}, \mathrm{R})$ were oven dried at $103{ }^{\circ} \mathrm{C}$ for $48 \mathrm{~h}$ before treatment for determination of initial mass. Heat treatment was carried out on wood blocks at $220^{\circ} \mathrm{C}$ for 20 $\mathrm{h}$ under inert atmosphere in a Carlo Erba GC oven. The oven temperature was increased by $20^{\circ} \mathrm{C} \mathrm{min}{ }^{-1}$ from room temperature to $220^{\circ} \mathrm{C}$ for $1 \mathrm{~h}$, followed by heating treatment at $220^{\circ} \mathrm{C}$ for $20 \mathrm{~h}$. Mass loss after heat treatment was determined by Equation 1:

$$
\operatorname{Mass} \operatorname{loss}(\%)=\left(\left(M_{0}-M_{1}\right) / M_{0}\right) \times 100
$$

where $\mathrm{M}_{0}$ was the initial mass of oven-dried (at $103^{\circ} \mathrm{C}$ ) wood sample before heat treatment and $\mathrm{M}_{1}$ was the mass of the same sample after heat treatment.

\section{Determination of chemical composition}

Heat treated and unheated wood samples were ground and the sawdust was extracted in Soxhlet apparatus for $24 \mathrm{~h}$ with different solvent of increasing polarity: dichloromethane, acetone, toluene/ethanol ( $2 / 1, \mathrm{v} / \mathrm{v})$, and water. Crude extract was then analysed with a Clarus 500 Gas Chromatogram (Perkin Elmer) according to already published procedures (Kebbi-Bendeker et al. 2014). 1 to $2 \mathrm{mg}$ of the dried extracts were silylated by adding $80 \mu \mathrm{L}$ of BSTFA/TMSCl $(99 / 1)$ and heated at $50^{\circ} \mathrm{C}$ for 12 hours. Then, the solvent was evaporated and extract derivatives were diluted in $1 \mathrm{~mL}$ ethyl acetate and transferred into a glass vials for gas chromatography analysis. GC-MS analysis was performed on a Clarus 500 gas chromatograph coupled to a Clarus 500 MS quadrupole mass spectrometer (Perkin Elmer Inc., USA). Gas chromatography was carried out on a 5\% diphenyl / 95\% dimethyl polysiloxane fused-silica capillary column (DB-5ms, $30 \mathrm{~m} \times 0,25 \mathrm{~mm}, 0,25 \mu \mathrm{m}$ film thickness, J\&W Scientific, USA) with helium as carrier gas at a constant flow of $1 \mathrm{~mL} / \mathrm{min}$. The gas chromatograph was equipped with an electronically controlled split/splitless injection port. The injection $(1 \mu \mathrm{L})$ was performed at $250^{\circ} \mathrm{C}$ in the splitless mode. The oven temperature program was as follows: $80^{\circ} \mathrm{C}$ for two minutes; increase from $80^{\circ} \mathrm{C}$ to $190^{\circ} \mathrm{C}$ at a rate of $10^{\circ} \mathrm{C} / \mathrm{min}$; increase from $190^{\circ} \mathrm{C}$ to $280^{\circ} \mathrm{C}$ at a rate of $15^{\circ} \mathrm{C} / \mathrm{min}$ and hold for five minutes; then $10^{\circ} \mathrm{C} / \mathrm{min}$ until $300^{\circ} \mathrm{C}$ hold for fourteen minutes. Ionisation was achieved under the electron impact mode ( $70 \mathrm{eV}$ ionisation energy). The source and transfer line temperatures were $250^{\circ} \mathrm{C}$ and $300^{\circ} \mathrm{C}$, respectively. Detection was carried out in scan mode: $\mathrm{m} / \mathrm{z}=45$ to $\mathrm{m} / \mathrm{z}=800$. The detector was switched off in the initial two minutes (solvent delay). Compounds were identified by comparison with spectra from the NIST (US National Institute of Standards and Technology, Gaithersburg, MD, USA) mass spectral library (Edition of 2005). Only qualitative analyses based on Total Ion Current (TIC). Three samples were measured for each wood in chemical composition. Holocellulose analysis was made according to Rowell (2005), cellulose was determined by Kurschner and Hoffner method, and Klason lignin was determinate according to Akinosho et al. (2017). Extractive contents, holocellulose, cellulose, hemicellulose and klason lignin were determined using formula by Equation 2, Equation 3, Equation 4, Equation 5, and Equation 6:

$$
\text { Extractive content }(\%)=(\text { Crude extract / initial mass of powder }) \times 100
$$

$$
\text { Holocellulose }(\%)=(\text { Mass of holocellulose / initial mass of sawdust }) \times 100
$$

$$
\text { Cellulose }(\%)=(\text { Mass of cellulose / initial mass of sawdust }) \times 100
$$


Hemicelullose $(\%)=$ Holocellulose $(\%)-$ cellulose $(\%)$

Klason lignin $(\%)=($ Mass of lignin/ initial mass of sawdust $) \times 100$

\section{Anti-swelling efficiency measurements}

The method of anti-swelling measurement was performed according to Engonga et al. (2000). The dimensions of samples were $30 \times 10 \times 20 \mathrm{~mm}^{3}$, according to longitudinal, tangential, and radial. There were six replicates for each treatment. Wood samples were dried at $103{ }^{\circ} \mathrm{C}$ for $48 \mathrm{~h}$ for determining dry volume. The blocks were soaked at water and, placed in a sealed desiccator to perform vacuum process for $1 \mathrm{~h}$. After releasing vacuum, the blocks were immersed for $24 \mathrm{~h}$ and then, their volume was measured to obtain wet volume. The volumetric swelling (Sv), and anti-swelling efficiency (ASE) were calculated. The volumetric swelling (Sv) and ASE was determined using formula by Equation 7 and Equation 8, respectively:

$$
\begin{aligned}
& S v(\%)=\frac{\left(V_{1}-V_{0}\right)}{V_{0}} \times 100 \\
& \operatorname{ASEv}(\%)=\frac{S_{u}-S_{m}}{S_{u}} \times 100
\end{aligned}
$$

where $\mathrm{v}_{1}$ was the volumetric dimension of the specimen after soaking and $\mathrm{v}_{0}$ was the oven-dry dimension before submersion. $\mathrm{s}_{\mathrm{u}}$ was the swelling of unheated wood and $\mathrm{s}_{\mathrm{m}}$ was the swelling of heated wood.

\section{Decay resistance}

The wood samples were tested to evaluate their resistance against fungal attack according to a procedure modified from EN 113 (1986) standard method. The wood samples consist of heated teak wood, unheated teak wood, and beech as a control wood. Dimension of samples were $30 \times 10 \times 5 \mathrm{~mm}^{3}(\mathrm{~L}, \mathrm{R}, \mathrm{T})$ with 6 replicates for each treatment. Wood samples were dried at $103{ }^{\circ} \mathrm{C}$ for $48 \mathrm{~h}$ and obtained their weight. White rot fungi of Trametes versicolor were inoculated on potato agar culture medium in petri dish and cultivated in an incubator at $22 \pm 2 \%$ temperature, $70 \pm 5 \%$ of relative humidity for 14 days. After mycelium has permeated the culture disc, wood samples were put in each petri dish and placed in incubator for 12 weeks. The decay resistance was measured by weight loss and moisture content of samples after fungal attack according to the formula given in Equation 9 and Equation 10, respectively:

$$
\begin{aligned}
& W L(\%)=\frac{M 0-M 1}{M 0} \times 100 \\
& M C(\%)=\frac{M_{0^{\prime}}-M_{1}}{M_{1}} \times 100
\end{aligned}
$$

where WL was the weight loss, and $\mathrm{M}_{0}$ and $\mathrm{M}_{1}$ was the oven dried weight of the samples before and after incubation, respectively. $\mathrm{MC}$ was moisture content, $\mathrm{M}_{0}$ ' was the wet weight of samples after incubation, and $M_{1}$ were the oven dried weight of the samples after incubation. 


\section{Wood coatings}

The dimensions of samples were $100 \times 10 \times 70 \mathrm{~mm}^{3}$ (L,T,R). In this study, we used commercial coatings, polyurethane water based and alkyd solvent based. For both finishes, two layers of coats were manually applied on wood with a brush. The first layer was dried after 4 hours for water-base coating and 24 hours for solvent-base coating. The second layer was applied after wood surface was sanded by sandpaper of 400 grit. The samples were air-dried for a week before being used for test. Wood samples were measured the color changes every weeks and the end of the test, wood samples were carried out scratch test.

\section{Accelerated weathering}

Simulation of exterior use was performed by QUV Accelerated Weathering Tester. Before weathering process, one layer of water proof coating was applied on the five uncovered sides of the samples. Three samples of each wood were air-dried for a week before being used for test. A weathering cycle consists in two phases. The first phase began by a long initial condensation phase for 24 hours: the water pan for condensation of the QUV was filled with water and heated with a resistance. The evaporation of water created a $100 \%$ of relative humidity for a temperature a $45^{\circ} \mathrm{C}$. This condensation was used to simulate the dew phenomena. The condensation phase was followed by the second one which is constituted of UV-light for $2 \mathrm{~h} 30$ and water spray for 30 minutes and which is repeated 48 times (the total duration of a cycle is then $168 \mathrm{~h}$ i.e. a week). The lights used on the QUV simulate solar radiation (sources type UVA-340 $\mathrm{nm}$ and illumination of $0,68 \mathrm{~W} / \mathrm{m}^{2}$ ). The distance between the UVA source and the samples was about $30 \mathrm{~mm}$ (Aloui et al. 2007). The test was carried out for eight weeks (1344 hours).

\section{Cross cut test}

Cross cut tape test was carried out according to ASTM D-3359 (2007) on weathered samples. There was a standard test method for measuring adhesion by means of tape test. The coating layer was cut into small squares that formed grids using a cutting tool. Pressure sensitive tape was then placed over the grid. The tape was then removed by rapidly pulling off the tape as close to an angle of $30^{\circ}$ as possible. Three replicates were used for each treatment. The adhesion strength was evaluated from the importance of removed squares or affected surface and classified following a scale from $0 \mathrm{~B}$ (more than $65 \%$ of surface affected) to $5 \mathrm{~B}$ (very good adhesion and surface non affected).

\section{Colour measurement}

Surface colour measurements were made in the CIE $L^{*}, a^{*}, b^{*}$ system with an ACS CS-5 Chroma-Sensor Applied Colour System. The measurements were carried out on uncoated sample, coated samples before and during exposure. The $L^{*}, a^{*}$, and $b^{*}$ parameters for each specimen were measured at seven contiguous positions on the wood surface.

\section{RESULTS AND DISCUSSION}

\section{Mass loss due to heat treatment}

Mass loss of heated wood is one of the important parameters in thermal modification for indicating quality (Esteves and Pereira 2009, Candelier et al. 2016). Mass losses of SRT and LRT were 13,40\% and 9,23\%, respectively. In previous study, mass loss in the range between $10 \%$ and $15 \%$ improves durability (Chaouch et al. 2010, Šušteršic et al. 2010), but mass loss above 16\% significantly decreases modulus of elasticity and modulus of rupture (Mburu et al. 2007). Durability of heated wood has strong correlated to mass loss (Candelier et al. 2016). A mass loss between $8,5-12 \%$ is enough to get the maximum reduction in swelling (Vu and Li 2010). In accordance to previous literatures, the mass losses of heated teaks (SRT and LRT) could improve their durability and stability. 


\section{Chemical composition}

The effect of the heat treatment on chemical composition of SRT and LRT is reported in Table 1. Similarly, to what is already described in the literature (Sivonen et al. 2002, Esteves and Pereira 2009, Candelier et al. 2013), both holocelullose and hemicelluloses contents decrease after heat treatment. This decrease was mainly due to hemicelluloses degradation, which was more susceptible to thermal degradation comparatively to cellulose, which the relative content of cellulose increased after heat treatment. Hemicelluloses content decreased from 26,26 to $10,71 \%$ for SRT and from 27,60 to $9,60 \%$ for LRT, while the relative content of cellulose increased from 41,10 to $45,96 \%$ for SRT and from 39,89 to 48,08\% for LRT. González-Peña et al. (2009) stated that the relative cellulose content increases firstly and it will be decreased when the mass losses reach $16 \%$. As a consequence of hemicellulose degradation in this work, the relative lignin content increased from 32,64 to $43,32 \%$ for SRT and from 32,51 to 42,31\% for LRT. González-Peña et al. (2009) found that the relative lignin content of heated beech at $210{ }^{\circ} \mathrm{C}$ increases from 23,4 to $28,8 \%$. This is attributed to condensation reactions of lignin (Kamdem et al. 2002, Boonstra and Tjeerdsma 2006). Especially when the temperature is above $200^{\circ} \mathrm{C}$, the samples result in more available products of depolymerisation hemicellulose, which can contribute to the polymerization reaction of lignin.

Table 1: Chemical composition of teak wood.

\begin{tabular}{ccccc}
\hline Chemical (\%) & Unheated-SRT & Heated-SRT & Unheated-LRT & Heated-LRT \\
\hline Holocellulose & $67,36 \pm 2,53$ & $56,68 \pm 0,23$ & $67,49 \pm 0,45$ & $57,69 \pm 0,01$ \\
Cellulose & $41,10 \pm 2,48$ & $45,96 \pm 0,75$ & $39,89 \pm 1,97$ & $48,08 \pm 0,57$ \\
Hemicellulose & $26,26 \pm 2,48$ & $10,71 \pm 0,75$ & $27,60 \pm 1,97$ & $9,60 \pm 0,57$ \\
Lignin & $32,64 \pm 010$ & $43,32 \pm 0,67$ & $32,51 \pm 0,13$ & $42,31 \pm 0,20$ \\
\hline
\end{tabular}

\section{Extractive content}

The total extractive content (TEC) of SRT was lower than that of LRT (Table 2). SRT in the age of 10 years contained only sapwood and juvenile wood. High proportion of heartwood was related to high total extractive contents. Darmawan et al. (2015) reported that SRT consist of $40 \%$ heartwood at 10 years old and LRT has $80 \%$ heartwood at 40 years old. The TEC of unheated SRT and LRT was 5,04 and 9,79\%. The result was in the range of study of Lukmandaru and Takahashi (2008). Extractive contents were obtained by extraction using successively four solvent with increasing polarity. Dichloromethane, acetone, and toluene/ethanol extract of unheated SRT were lower than these of unheated LRT, except in water extract. This indicates that SRT contained high polar extractive compound compared to LRT. The reduction of polar compounds in the extractive shows transformation of sapwood to heartwood, while non-polar compounds in the extractives increase with the age of heartwood (Niamké et al. 2011).

After heat treatment, the total extractive contents of short and long rotation decreased by $3,77 \%$ and $30,44 \%$ respectively. It was caused by the evaporation of volatile compounds. Candelier et al. (2013) found that reduction of extractive content could be caused by the evaporation of low molecular weight compounds generated during heat treatment. The reduction of total extractive content of LRT was higher than that of short rotation. The high extractive contents in LRT could make the evaporation of volatile compounds easier. 
Table 2: Extractive content of teak wood.

\begin{tabular}{|c|c|c|c|c|}
\hline Extractives (\%) & Unheated-SRT & Heated-SRT & Unheated-LRT & Heated-LRT \\
\hline Dichloromethane & $1,41 \pm 0,07$ & $1,19 \pm 0,74$ & $4,65 \pm 0,12$ & $3,52 \pm 0,03$ \\
\hline Acetone & $0,53 \pm 0,06$ & $1,02 \pm 0,22$ & $1,35 \pm 0,38$ & $1,58 \pm 0,36$ \\
\hline Toluene/ ethanol & $0,54 \pm 1,06$ & $0,69 \pm 0,10$ & $1,80 \pm 1,13$ & $0,79 \pm 0,10$ \\
\hline Water & $2,56 \pm 0,45$ & $1,95 \pm 0,28$ & $1,98 \pm 0,45$ & $0,92 \pm 0,29$ \\
\hline Total & $5,04 \pm 0,87$ & $4,85 \pm 1,25$ & $9,79 \pm 1,44$ & $6,81 \pm 0,59$ \\
\hline
\end{tabular}

\section{Chemical composition of teak extractives}

Qualitative analysis of extractives by GCMS (Table 3) showed that squalene was the main component in dichloromethane soluble extractives of unheated teak $(67,05 \%$ and $14,4 \%$ relative to TIC (Total Ion Current) for LRT and for SRT, respectively). After heat treatment, squalene content decreased to 30,94\% in the LRT, while squalene could not be detected anymore in the SRT. Both teaks contained 2-methylanthraquinone (tectoquinone), whereas 2-tert-butylanthraquinone was only found in unheated LRT. Windeisen et al. (2003) identified similar compounds (2-methylanthraquinone and 2-tert-butylanthraquinone) in teak wood acetone extract. Dichloromethane, acetone, and toluene/ethanol extracts of unheated LRT contained tectoquinone with a percentage ranging from 23,19 to $44,03 \%$. Tectoquinone was only found in dichloromethane and acetone extracts $(5,80$ and $11,79 \%$ respectively) for unheated SRT. After heat treatment, the relative percentage of tectoquinone of SRT and LRT decreased in acetone and toluene-ethanol extract, while it increased in dichloromethane extract. This behaviour may be due to the higher thermal stability of tectoquinone compared to other components of dichloromethane extract.

Table 3: Major components identified in the extractives.

\begin{tabular}{lllll}
\hline Solvent & $\begin{array}{c}\text { Retention } \\
\text { time }\end{array}$ & Name of product & Match & $\begin{array}{l}\text { TIC } \\
\mathbf{( \% )}\end{array}$ \\
\hline Unheated LRT & & & & \\
Dichloromethane & 17,21 & 2-Methylantraquinone (Tectoquinone) & 868 & 23,19 \\
& 21,25 & Squalene & 866 & 67,05 \\
Acetone & 17,08 & 2-Methylantraquinone (Tectoquinone) & 863 & 44,03 \\
& 17,55 & 2-tert-Butylanthraquinone & 718 & 0,77 \\
\cline { 2 - 6 } Toluene:ethanol & 17,19 & 2-Methylantraquinone (Tectoquinone) & 852 & 32,16 \\
& 17,59 & 2-tert-Butylanthraquinone & 635 & 26,15 \\
\hline Heated LRT & & & & \\
Dichloromethane & 17,08 & 2-Methylantraquinone (Tectoquinone) & 891 & 54,88 \\
& 21,25 & Squalene & 850 & 30,94 \\
\cline { 2 - 6 } Acetone & 17,11 & 2-Methylantraquinone (Tectoquinone) & 863 & 37,81 \\
& 21,26 & Squalene & 843 & 1,85 \\
\cline { 2 - 6 } Toluene & 11,34 & Vanilin lactoside & 705 & 3,83 \\
& 13,82 & Syringaldehyde & 766 & 21,07 \\
& 17,25 & 2-Methylantraquinone (Tectoquinone)- & 866 & 13,82 \\
\hline Unheated SRT & & & & \\
dichloromethane & 17,38 & 2-Methylantraquinone (Tectoquinone) & 849 & 5,8 \\
& 21,25 & Squalene & 820 & 14,4 \\
\cline { 2 - 6 } Acetone & 16,66 & 4-tert-Butyl-2-phenylphenol & 742 & 3,54 \\
& 17,37 & 2-Methylantraquinone (Tectoquinone) & 609 & 11,79 \\
\hline Heated SRT & & & & \\
Dichloromethane & 10,77 & Vanilin & 754 & 6,7 \\
& 13,35 & Syringaldehyde & 873 & 29,3 \\
Acetone & 17,11 & 2-Methylantraquinone (Tectoquinone) & 885 & 18,9 \\
\hline & 13,82 & Syringaldehyde - & 817 & 10,47 \\
\hline
\end{tabular}

\section{Dimensional stability}

The volumetric swelling is one of the parameters for indicating dimensional stability (Figure 1). The swelling of unheated SRT $(13,10 \%)$ was higher compared to that of unheated LRT $(12,01 \%)$. After heat treatment, 
swelling of SRT and LRT decreased to be $4,60 \%$ and 4,93\% respectively. Anti-swelling efficiency (ASE) was difference in swelling between before and after treatment. The anti-swelling efficiency of SRT was greater than that of LRT, resulting in $64,87 \%$ and $58,93 \%$ respectively. SRT resulted in better ASE value than LRT and improved their dimensional stability. Chemical processes explained about the improvement of dimensional stability in heated teak. Hemicellulose has high hygroscopic behavior and is not resistant to high temperature, which is easily degraded at low temperature (Bekhta and Niemz 2003). Releasing acetic acid and reducing hydroxyl group in hemicellulose play an important role to decrease moisture content and accessibility of $\mathrm{OH}$ group (Vu and Li 2010, Rautkari et al. 2013). Therefore, the loss of hemicellulose in the heated woods could improve their stability.

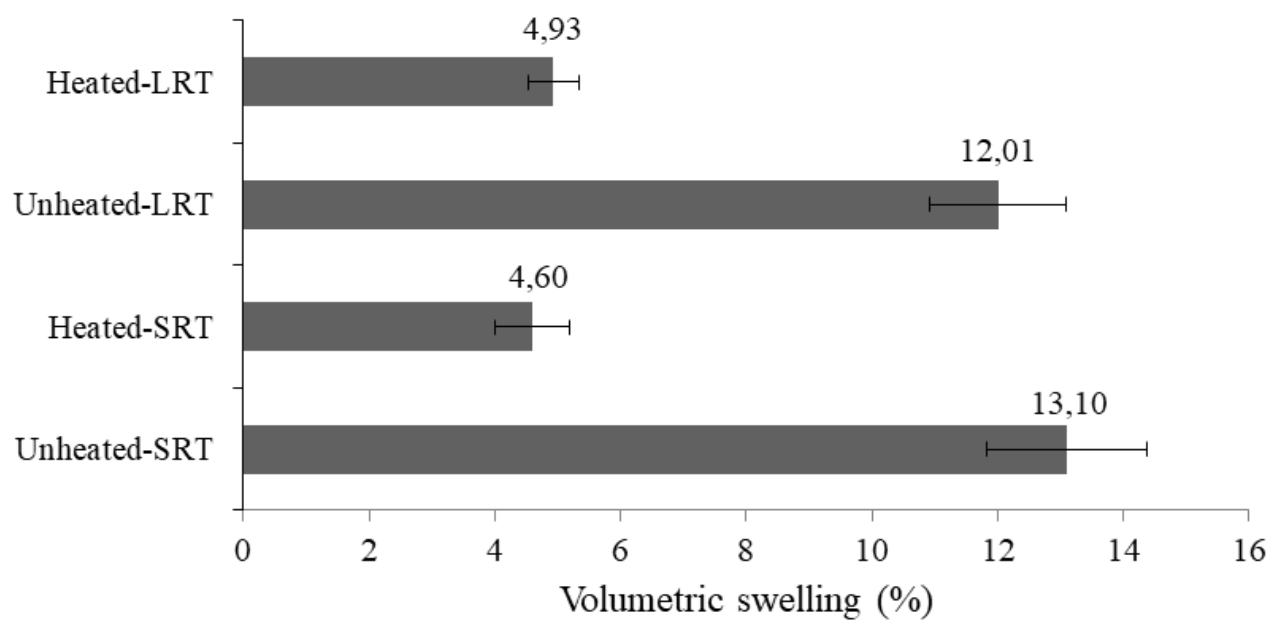

Figure 1: Volumetric swelling of teak wood.

\section{Decay resistance}

Compared to unheated woods, the durability of heated teaks against white rot fungi was improved (Figure 2). According Indonesia national standard 7207 (2014), unheated LRT and heated LRT were classified to class II (durable) and class I (very durable), respectively. Meanwhile, unheated short rotation teak and beech (control sample) fall under class IV (non-durable) and class V (very non-durable), respectively. The inhibition of fungal growth was related to moisture content and presence of toxic chemical. After heat treatment, wood was predicted to be less hydrophilic due to reduction in hemicellulose content. Measurement of moisture content after fungal attack reduced up to 66\% (heated SRT) and 25\% (heated LRT). Although the moisture content was high enough, fungi was difficult to attack wood. This indicated that hydrophobic character in heated wood was not at the origin of the improvement of durability. Mburu et al. (2008) reported that improvement of decay resistance in heated Grevillea robusta is due to toxic compounds produced during degradation thermal. Degradation of amorphous cellulose at high temperature and modification of lignin also affect to $T$. versicolor attack (Boonstra et al. 2007). Lignin provides a significant protection with high lignin level and presence of guaiacyl lignin considered to present better natural protection than low lignin level and syringyl lignin (Daniel 2003). Extractable compound of heated teak was identified as vanillin and syringaldehyde (Table 3). Vanillin and syringaldehyde were derivated from guaiacyl and syringil lignin, respectively. Vanillin is known to prevent or slow down fungal growth (Highley and Micales 1990). In addition, tectoquinone is identified as bioactive compound for inhibition of fungal growth (Haupth et al. 2003) in unheated teak. However, toxic compound produced by heat treatment was more useful for inhibiting fungal attack. 


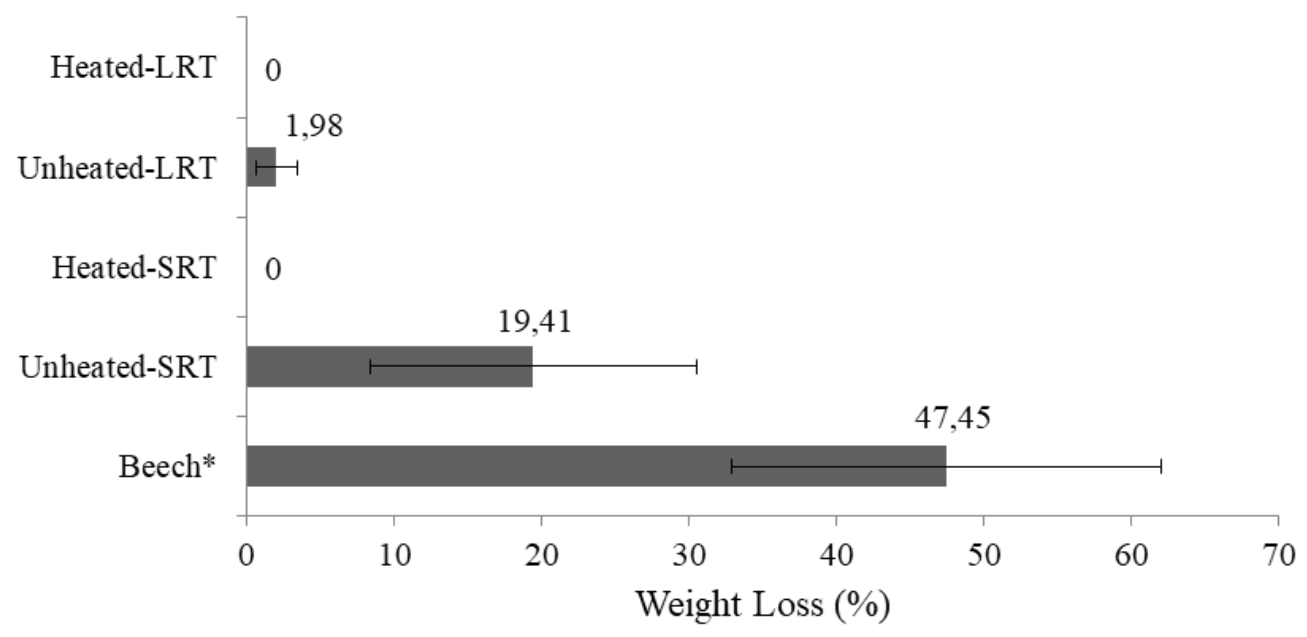

Figure 2: Weight losses of teak wood samples to white rot decay fungus T. versicolor.

\section{Bonding quality}

The adhesion of coatings after weathering was assessed according to the ASTM D-3359 (2007) standard. The results were reported in Table 4. The data showed a good adhesion for solvent-based coatings whatever the substrate, SRT or LRT, heated or unheated, since in all cases, the percentage of detachment was very low around less than $5 \%$ of area removed (4B). Conversely the adhesion of water-based coatings on heated or unheated was very bad both on SRT (1B /35-65\% of area removed) and LRT (2B /15-35\% of area removed). Surface layer of water-based coating had poor properties against aggressive factors, merely water during the condensation and water spray steps in weathering device. Indeed, water-based coatings contain hydrophilic substances that can be lixiviated hence a decrease of cohesiveness of the films and a loss of adherence. Solvent-based coating spreads completely during film formation even without the presence of solvent. The ease of spreading of solvent-based coating leads to beneficial substrate wetting and penetration in wood. Darmawan et al. (2018) found the lower equilibrium contact angle of solvent-based coating indicates that it should create more intimate contact on the wood surface than that of the water-based coating. However, Petrič et al. (2007) explained although hydrophobic character of oil-heated-treated Scot pine increase, exterior acrylic waterborne coatings show better wetting. Acrylic waterborne shows better performance after weathering for 5 years in heated wood than unheated wood (Jämsä et al. 2000). According to those explanation, bonding quality depended on application of coatings system. In this study, polyurethane waterborne was not suitable for exterior application, but this could be applied in interior application.

Table 4: Classification of adhesion test result in teak wood after weathering.

\begin{tabular}{lcc}
\hline \multirow{1}{*}{ Samples } & \multicolumn{2}{c}{ Coated by } \\
\cline { 2 - 3 } & Water based & Solvent based \\
\hline Unheated-SRT & 1B & $4 \mathrm{~B}$ \\
Heated- SRT & OB & $4 \mathrm{~B}$ \\
Unheated-LRT & 2B & $4 \mathrm{~B}$ \\
Heated-LRT & 1B & $4 \mathrm{~B}$ \\
\hline
\end{tabular}




\section{Visual aspect and colour changes}

The evolution of aspect and colour for the different samples is shown in Figure 3 and Figure 4. Before weathering, the colour of SRT and LRT was greatly modified by heat treatment (important darkening) and also by the application of a water or solvent-based coating. Degradation of wood polymers (hemicellulose and lignin) and extractive compound were predicted to participate a color formation of wood heated, and similar reports were noted by Sundqvist and Moren (2002), Sehlstedt-Persson (2003). At the end of the test, the adhesion of water based coating was lower than the one of solvent-based coating. This was indicated by the apparition of cracks during the weathering process. Moreover, dark stains and white defects could be observed and appeared more rapidly on unheated wood samples covered by water-based coating. White defects indicated loss of coating adhesion and dark stain may originate from the migration of extractives. The water-soluble extractive migrated through wood substrate and water-based coating, and made yellow or brown discoloration on the coating surface. On the water-based coated unheated SRT, the dark colour appeared after the first week exposure (versus 5 weeks for unheated LRT), and it almost covered the entire surface of wood at the end of the exposure. For example, oak species coated by water-borne coatings presents also the problem of the extractive bleed because of the presence of phenolic compound such as tannins (Aloui et al. 2007).

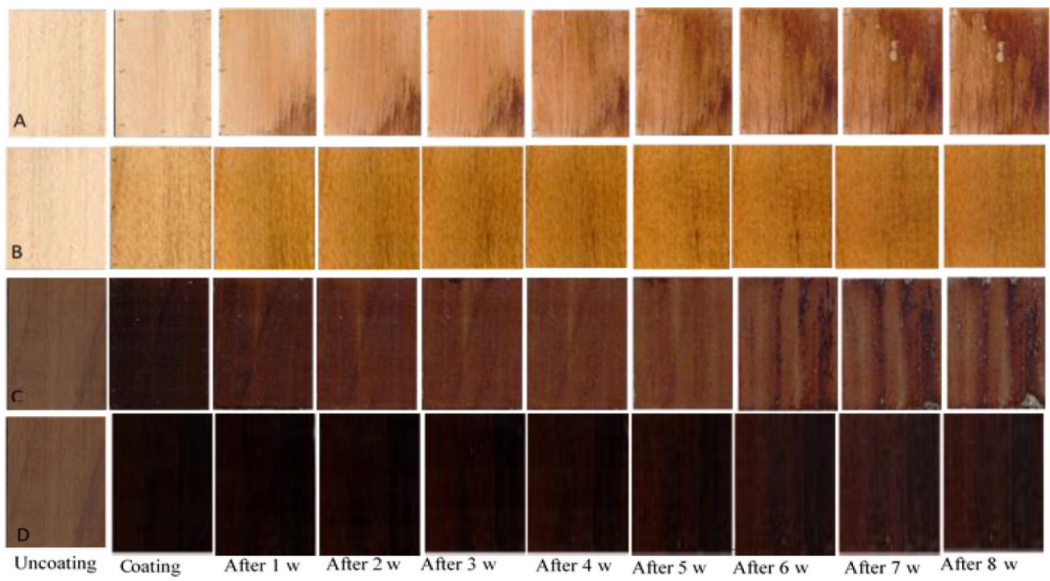

Figure 3: Visual colour changes of SRT before and after weathering process; A: unheated -water based, B: unheated-solvent based, C: heated-water based, D: heated-solvent based.

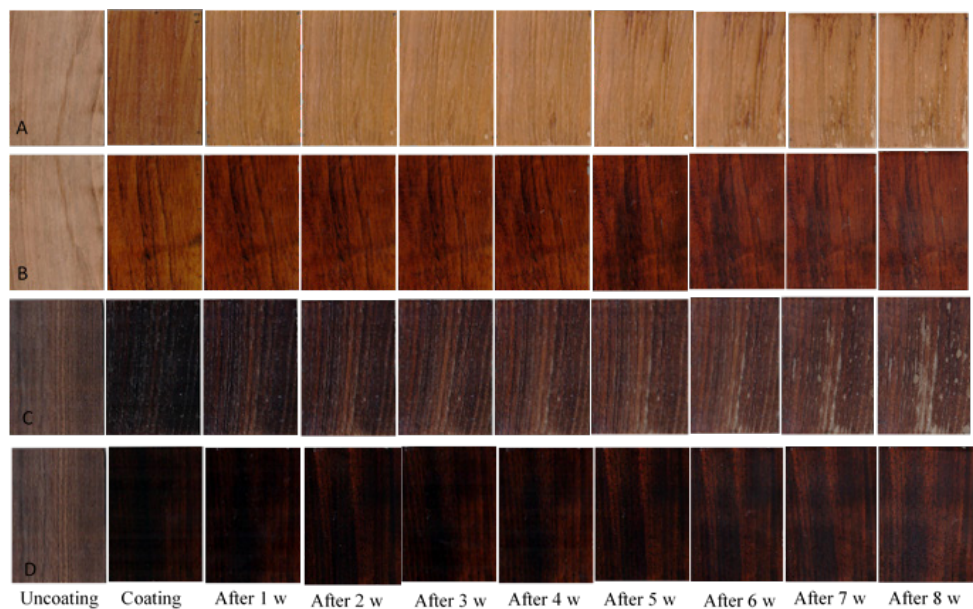

Figure 4: Visual colour changes of LRT before and after weathering process; A: unheated -water based, B: unheated-solvent based, C: heated-water based, D: heated-solvent based.

The colour of heated teaks seemed more uniform than that of unheated teaks. Nevertheless, the dark-coloured and white defects were still found on surface of heated teaks especially for samples covered by water based coating. Nevertheless the apparition of these defects seems to be delayed (one week for unheated SRT versus six weeks for heated one for example). This result can be related to the amount of water-soluble extractive in wood. Indeed, we observed that this amount decreased after heat treatment. Whatever the substrate, solvent-based coatings have a good adhesion and the visual aspect of samples is more homogeneous. We just 
observed a darkening of unheated samples (Figure 3B and Figure 4B) and a lightening of heat treated ones (Figure 3D and Figure 4D) during weathering.
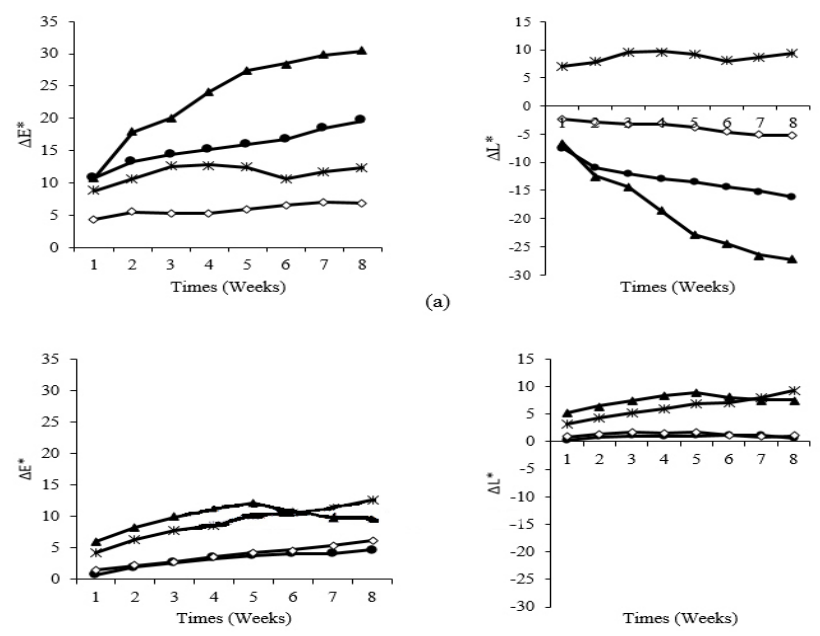

(b)

Figure 5: The total colour difference ( $\left.\Delta E^{*}\right)$, lightness $\Delta L^{*}$ of SRT (a) and LRT (b).

The total colour difference $\left(\Delta E^{*}\right)$ of teak coated by water- and solvent-based coatings increased during weathering test (Figure 5). The overall colour changes of coated unheated wood, especially on short rotation, were greater than those of coated treated wood. $\Delta E^{*}$ is quite well related to luminance changes $\Delta L^{*}$. It is especially observed for unheated SRT coated with water-based coating which underwent a great decrease of luminance, while $\Delta L^{*}$ value of heated SRT tends to be more stable. Heated teaks were better photo-stabilized than unheated wood. It was predicted by an increase of lignin content during heat treatment process. The best photo-stability of thermally modified wood could be explained by the increase of lignin stability by condensation (Ayadi et al. 2013).

\section{CONCLUSIONS}

The heated teaks presented a decrease in hemicelluloses content, while the lignin content increased. Overall extractives contents, and especially tectoquinone content, were higher in long rotation than in short rotation teak explaining the higher decay and termite durability of long rotation teak wood. Even if small amounts of tectoquinone can still be detected after heat treatment, overall extractives contents decreased for both teak samples. The short rotation teak present improved dimensional stability and decay resistance after heat treatment. After weathering, the adhesion strength of a solvent based coating was good whatever the type of wood but it decreased for water based coating and all the more that heat treated wood has been used. Besides, heated teaks could better resist to photo-degradation compared to unheated teaks.

\section{ACKNOWLEDGEMENTS}

The authors gratefully acknowledge to the Ministry of Education and Culture (KEMENDIKBUD) and RISTEK-DIKTI for research work.

EA 4370 LERMAB is supported by a grant overseen by the French National Research Agency (ANR) as part of the "Investissements d'Avenir" program (ANR-11-LABX-0002-01, Lab of Excellence ARBRE).

\section{REFERENCES}

Ahajji A.; Diouf, P.N.; Aloui, F.; Elbakali, I.; Perrin, D.; Merlin, A.; George, B. 2009. Influence of heat treatment on antioxidant properties and color stability of beech and spruce wood and their extractives. Wood Sci Technol 43 (1): 69-83. 
Ragaukas, A.J. 2017. Effect of biomass accessibility and klason lignin contents during consolidated bioprocessing in Populus trichocarpa. ACS Sustain Chem Eng 5 (6): 5075-5081.

Aloui, F.; Ahajji, A.; Irmouli, Y.; George, B.; Charrier, B.; Merlin, A. 2007. Inorganic UV absorbers for the photostabilisation of wood-clear coating system: comparison with organic UV absorbers. Applied Surface Science 253 (8): 3737-3745.

ASTM International. 2007. Standard test methods for adhesion by tape test ASTM D-3359. 2007. West Conshohocken.

Ayadi, N.; Lejeune, F.; Charrier, F.; Charrier, B.; Merlin, A. 2013. Color stability of heat-treated wood during artificial weathering. Holz Roh Werkst 61 (3): 221-226.

Basri, E.; Wahyudi, I. 2013. Wood basic properties of jati plus perhutani from different ages and their relationships to drying properties and qualities. JPHH 31(2): 93-102.

Bekhta, P.; Niemz, P. 2003. Effect of high temperature on the change in color, dimensional stability and mechanical properties of spruce wood. Holzforschung 57 (5):539-546.

Bhat, K.M.; Florence, E.J.M. 2003. Natural decay resistance of juvenile teak wood grown in high input plantations. Holzforschung 57 (5): 453-455.

Boonstra, M.J.; Acker, J.V.; Kegel, E. 2007. Optimisation of a two-stage heat treatment process: durability aspects. Wood Sci Technol 41 (1): 31-57.

Boonstra, M.J.; Tjeerdsma, B. 2006. Chemical analysis of heated softwoods. Holz Roh Werkst 64 (3): 204-211.

Candelier, K.; Dumarcay, S.; Petrissans, A.; Desharnais, L.; Gérardin, P. 2013. Comparison of chemical composition and decay durability of heat treated wood cured under different inert atmospheres: nitrogen or vacuum. Polym Degrad Stab 98 (2): 677-681.

Candelier, K.; Thevenon, M.F.; Petrissans, A.; Dumarcay, S.; Gérardin, P.; Petrissans, M. 2016. Control of wood thermal treatment and its effects on decay resistance: a review. Ann For Sci 73 (3): 571-583.

Chaouch, M.; Petrissans, M.; Petrissans, A.; Gérardin, P. 2010. Use of wood elemental composition to predict heat treatment intensity and decay resistance of different softwood and hardwood species. Polym Degrad Stab 95 (12):2255-2259.

Daniel, G. 2003. Wood deterioration and preservation. American Chemical Society press, Washington DC, pp 34-72.

Darmawan, W.; Rahayu, I.S.; Tanaka, C.; Marchal, R. 2006. Chemical and mechanical wearing of high speed steel and tungsten carbide tools by tropical woods. JTFS 18 (4): 166-172.

Darmawan, W.; Nandika, D.; Sari, R.K.; Sitompul, A.; Rahayu, I.; Gardner, D. 2015. Juvenile and mature wood characteristics of short and long rotation teak in Java. IAWA J 36(4): 429-443.

Darmawan, W.; Nandika, D.; Noviyanti, E.; Irsan, A.; Dumasari, L.; Douglas, G.; Gérardin, P. 2018. Wettability and bonding quality of exterior coatings on jabon and sengon wood surface. $J$ Coatings Technol 15(1): 95-104.

European committee for standardization. EN. 1986. Wood preservatives-determination of toxic values of wood preservatives against wood destroying basidiomycetes cultured on agar medium EN 113 .1986.

Engonga, P.; Schneider, R.; Gérardin, P.; Loubinoux, B. 2000. Preparation and dimensional stability of wood grafted with alkyl chains. Holz Roh Werkst 58 (4): 284-286.

Esteves, B.M.; Pereira, H.M. 2009. Wood modification by heat treatment: a review. BioResources 4(1):370-404. 
Garcia, R.A.; Lopes, J.D.O.; Nascimento, A.M.; Latorraca, J.V.D.F. 2014. Color stability of weathered heat-treated teak wood. Maderas-Cienc Tecnol 16 (4): 453-462.

Gérardin, P. 2016. New alternatives for wood preservation based on thermal and chemical modification of wood-a review. Ann For Sci 73(3): 559-570.

González-Peña, M.M.; Curling, S.F.; Hale, M.D.C. 2009. On the effect of heat on the chemical composition and dimensions of thermally-modified wood. Polym Degrad Stab 94 (12): 2184-2193.

Hakkou, M.; Petrissans, M.; Gérardin, P.; Zoulalian, A. 2006. Investigations of the reasons for fungal durability of heat-treated beech wood. Polym Degrad Stab 91 (2):393-397.

Haupt, M.; Leithoff, H.; Meier, D.; Puls, J.; Richter, H.G.; Faix, O. 2003. Heartwood extractive and natural durability of platation-grown teakwood (Tectona grandis L.) - a case study. Holz Roh Werkst 61 (6): 473-474.

Highley, T.L.; Micales, J.A. 1990. Effect of aromatic monomers on production of carbohydrate-degrading enzymes by white-rot and brown-rot fungi. FEMS Microbiol Lett 66 (1-3): 15-22.

Hill, C.A.S. 2006. Wood modification: chemical, thermal and other processes. John willey \& sons: England, p. 99-127. 293.

Hillis, W.E. 1984. High temperature and chemical effects on wood stability. Wood Sci Technol 18: 281-

Huang, X.; Kocaefe, D.; Kocaefe, Y.; Boluk, Y.; Pichette, A. 2012. Study of the degradation behavior of heat-treated jack pine (Pinus banksiana) under artificial sunlight irradiation. Polym Degrad Stab 97 (7): $1197-1214$.

Indonesia National Standard. 2014. Wood resistance against microorganism 7207. National Standardization Agency: Indonesia.

Jämsä, S.; Ahola, P.; Viitaniemi, P. 2000. Long-term natural weathering of coated thermowood. Pigmen Resin Technol 29(2): 68-74.

Kamdem, D.P.; Pizzi, A.; Jermannaud, A. 2002. Durability of heat-treated wood. Holz Roh Werkst 60 (1): $1-6$

Kebbi-Benkeder, Z.; Colin, F.; Dumarcay, S.; Gérardin, P. 2014. Quantification and characterization of knotwood extractives of 12 European sofwood and hardwood species. Ann For Sci 72(2): 277-284.

Li, M.Y.; Cheng, S.C.; Li, D.; Wang, S.N.; Huang, A.M.; Sun, S.Q. 2015. Structural characterization of steam-heat treated Tectona grandis wood analyzed by FT-IR and 2D correlation spectroscopy. Chin Chem Lett 26 (2): 221-225.

Lukmandaru, G.; Takahashi, K. 2008. Variation in the natural termite resistance of teak (Tectona grandis Lin. Fil.) wood as a function of tree age. Ann For Sci 65 (7): 8p.

Lukmandaru, G. 2011. Variability in the natural termite resistance of plantation teak wood and its relations with wood extractive content and color properties. JFR 8 (1): 17-31.

Martawijaya, A.; Kartasujana, I.; Kadir, K.; Prawira, S. 2005. Atlas kayu Indonesia. Forest Products Research Institute: Bogor.

Mburu, F.; Dumarcay, S.; Bocquet, J.F.; Petrissans, M.; Gérardin, P. 2008. Effect of chemical modifications caused by heat treatment on mechanical properties of Grevillea robusta wood. Polym Degrad Stab 93 (2): 401-405.

Mburu, F.; Dumarcay, S.; Huber, F.; Petrissans, M.; Gérardin, P. 2007. Evaluation of thermally modified Grevillea robusta heartwood as an alternative to shortage of wood resource in Kenya: Characterisation of physicochemical properties and improvement of bio-resistance. Bioresource Technology 98 (18): 3478-3486. 
Méndez-Mejías, L.D.; Moya, R. 2016. Effects on density, shrinking, color changing, and chemical surface analysis through FTIR of Tectona grandis thermo-treated. Sci For 44 (112): 811-820.

Miranda, I.; Sousa, V.; Helena, P. 2011. Wood properties of teak (Tectona grandis) from a mature unmanaged stand in East Timor. $J$ Wood Sci 57 (3): 171-178.

Moya, R.; Bond, B.; Quesada, H. 2014. A review of heartwood properties of Tectona grandis trees from fast-growth plantations. Wood Sci Technol 48 (2): 411-433.

Niamké, F.B.; Amusant, N.; Charpentier, J.P.; Chaix, G.; Baissac, Y.; Boutahar, N.; Adima, A.A.; Kati-Coulibaly, S.; Jay-Allemand, C. 2011. Relationship between biochemical attributes (non-structural carbohydrates and phenolics) and natural durability against fungi in dry teak wood (Tectona grandis L. f.). Ann For Sci 68 (1): 201-211.

Petrič, M.; Knehtl, B.; Krause, A.; Militz, H.; Pavlič, M.; Pétrissans, M.; Rapp, A.; Tomazič, M.; Welzbacher, C.; Gérardin, P. 2007. Wettability of waterborne coatings on chemically and thermally modified pine wood. $J$ Coat Technol Res 4 (2): 203-206.

Rautkari, L.; Hill, CAS.; Curling, S.; Jalaludin, Z.; Ormondryoyd, G. 2013. What is the role of the accessibility of wood hydroxyl group in controlling moisture content? J Master Sci 48(18): 6352-6356.

Richter, H.G.; Leithoff, H.; Sonntag, U. 2003. Characterisation and extension of juvenile wood in plantation grown teak (Tectona grandis L.f) from Ghana. In: Proceedings of the international conference on quality timber products of teak from sustainable forest management, 2-5 December, Peechi, Indi.

Roux, M.L.; Eozniak, E.; Miller, E.R.; Boxall, J.; Bottcher, P.; Kropf, F.; Sell, J. 1988. Natural weathering of various surface coatings on five at four European sites. Holz Roh Werkst 46 (5): 165-170. State.

Rowell, R.M. 2005. Handbook of Wood Chemistry and Wood Composites. CRC Press LLC: United

Sehlstedt-Persson, M. 2003. Color response to heat-treatment of extractives and sap from pine and spruce. In: $8^{\text {th }}$ International IUFRO wood drying conference, 24-29 August, Brasov, Romania.

Sivonen, H.; Maunu, S.L.; Sundholm, F.; Jamsa, S.; Viitaniemi, P. 2002. Magnetic resonance studies of thermally modifies wood. Holzforschung 56 (6):648-654.

Sundqvist, B.; Moren, T. 2002. The influence of wood polymers and extractives on wood color induced by hydrothermal treatment. Holz Roh Werkst 60 (5): 375-376.

Šušteršic, Z.; Mohareb, A.; Chaouch, M.; Petrissans, M.; Petric, M.; Gérardin, P. 2010. Presiction of the decay resistance of heat treated wood on basis of its elemental composition. Polym Degrad Stab 95 (1):94-97.

Thulasidas, P.K.; Bhat, K.M. 2007. Chemical extractive compounds determining the brown-rot decay resistance of teak wood. Holz Roh Werkst 65 (2): 121-124.

Uribe, B.E.B.; Ayala, O.A. 2015. Characterization of three wood species (oak, teak, and chanul) before and after heat treatment. J Indian Acad Wood Sci 12 (1): 54-62.

Vernois, M. 2001. Heat treatment of wood in France-State of the art. Centre Technique du Bois et de l'Ameublement, Paris. Available online $<$ http://www.thermaltreatedwood.com/Worldwide/France.pdf $>$ (access 26/02/2018).

Vu, M.T.; Li, J. 2010. Effect of heat treatment on the change in color and dimensional stability of acacia hybrid wood. BioResources 5 (2): 1257-1267.

Windeisen, E.; Klassen, A.; Wegener, G. 2003. On the chemical characterization of plantation teakwood from Panama. Holz Roh Werkst 61 (6): 416-418. 